\title{
Kajian Potensi Daur Ulang Sampah Makanan Restoran di Kota Padang
}

\author{
Yommi Dewilda ${ }^{1, *}$, Rizki Aziz², Mhd. Fauzi ${ }^{3}$ \\ 1,2,3 Jurusan Teknik Lingkungan, Fakultas Teknik, Universitas Andalas, Kampus Limau Manis, Padang, \\ 25163, Indonesia \\ *Koresponden email: yommidewilda@eng.unand.ac.id
}

Diterima : 31 Mei 2019

Disetujui: 2 Juni 2019

\begin{abstract}
The purpose of this research is to study the recycling potency of food waste from restaurants in Padang City by measuring the food waste generation and its composition. Sampling and analysis were carried out based on SNI 19-3964-1994. It was performed for eight consecutive days at fifteen different sampling locations which include restaurants, cafes, fast food, and food courts. The result of this research showed that the average generation unit of restaurant food waste in the city of Padang was $0.105 \mathrm{~kg} / \mathrm{cap} /$ day in weight units or 0.955 liters/cap/day in unit volume. The total generation of restaurant food waste was 132 liters/day which consists of organic waste (food scraps, leaves, fruit skin, vegetables, eggshells, bones), plastic (plastic bottles, packaging, bags, straws , and spoons), paper (tissue, packaging paper, paper containers, cartons), and others (styrofoam, broken glass, smoked cigarette remains, cans, glass bottles). Organic waste has the largest percentage by the composition of $70.69 \%$, and that of plastic was at $11.35 \%$. The study further showed that the recycling potency of restaurant food waste in Padang City was made up of $7.65 \%$ paper, $51.32 \%$ plastic, $59.86 \%$ glass, $100 \%$ nonferrous metal and $91.71 \%$ organic waste. Conclusively, recycling and composting method were recommended to process the restaurant food waste.
\end{abstract}

Keyword: characteristic, composition, food waste of restaurant, generation, Padang City, recycling potency

\begin{abstract}
Abstrak
Penelitian ini bertujuan untuk mengkaji potensi daur ulang sampah makanan restoran di Kota Padang melalui pengukuran timbulan dan komposisi sampah makanan restoran di Kota Padang. Sampling timbulan dan penentuan jumlah sampel dilakukan berdasarkan SNI 19-3964-1994 yang dilakukan selama delapan hari berturut-turut dengan lokasi pengambilan sampel pada 15 titik meliputi rumah makan, cafe, fast food dan food court. Hasil Penelitian menunjukkan satuan timbulan rata-rata sampah makanan restoran di Kota Padang adalah sebesar 0,105 kg/o/hari dalam satuan berat atau sebesar 0,955 liter/o/hari dalam satuan volume. Timbulan sampah makanan restoran di Kota Padang sebesar $132 \mathrm{l} / \mathrm{h}$ terdiri dari sampah organik (sisa makanan, daun, sisa bahan makanan, kulit buah, sayur, cangkang telur, tulang), sampah plastik (botol plastik, plastik kemasan, kantong plastik, sedotan, sendok plastik), kertas (tissue, kertas pengemas, wadah kertas, karton), dan lain-lain (styrofoam, pecahan kaca, sisa rokok, kaleng, botol kaca). Komposisi sampah terbesar adalah sampah organik dengan persentase 70,69\%, sedangkan komposisi sampah plastik sebesar 11,35\%. Potensi daur ulang sampah makanan restoran di Kota Padang terdiri dari kertas 7,65\%, plastik 51,32\%, kaca 59,86\%, logam non ferrous $100 \%$ dan sampah organik 91,71\%. Pengolahan sampah makanan restoran di Kota Padang yang direkomendasikan dapat berupa metode daur ulang dan pengomposan.
\end{abstract}

Kata kunci: karakteristik, komposisi, Kota Padang, potensi daur ulang, restoran, sampah makanan, timbulan

\section{Pendahuluan}

Undang-Undang Nomor 18 Tahun 2008 tentang Pengelolaan Sampah mendefinisikan bahwa sampah adalah sisakegiatan keseharian manusia dan atau proses alam yang berbentuk padat. Meningkatnya jumlah sampah yang dihasilkan seiring dengan pertumbuhan yang terjadi di wilayah tersebut, baik pertumbuhan penduduk maupun pertumbuhan timbulan sampah yang dipengaruhi oleh indeks pertumbuhan pangan, industri dan pendapatan perkapita.
Sampah merupakan salah satu permasalahan yang umum terjadi di Indonesia. Masalah sampah yang tak pernah selesai di sebagian besar kota yang ada di Indonesia disebabkan pada sistem pengelolaan yang tidak sesuai dengan peraturan di Indonesia. Menurut Damanhuri dan Padmi (2016) hanya 40\% sampah yang masuk ke TPA, sisanya ditanggulangi oleh penghasil sampah seperti dibakar (35\%), ditimbun dalam tanah $(7,5 \%)$, dikompos $(1,61 \%)$ dan beberapa upaya termasuk daur ulang, dibuang dimana saja, seperti 
selokan, drainase atau badan air lainnya. Pengelolaan sampah yang tidak semestinya akan menyebabkan masalah lingkungan, seperti sebagai vektor penyakit, pencemaran terhadap air, pencemaran terhadap udara, pencemaran terhadap tanah maupun air tanah. Selain menyebabkan masalah lingkungan, sampah juga akan mengurangi nilai estetika suatu daerah akibat timbulan sampah yang dihasilkan oleh masyarakat.

Kota Padang sebagai salah satu tujuan wisata di Indonesia mengalami pertumbuhan pada sektor perekonomian. Halini ditandaidenganterus munculnya berbagai rumah makan, cafe, restoran cepat saji dan tempat makan lainnya. Menurut Dinas Pariwisata dan Kebudayaan Kota Padang tahun 2017 tercatat sebanyak 230 restoran yang tersebar di Kota Padang. Hal ini akan berpotensi menyebabkan timbulnya sampah yang cukup besar dari sektor ini, terutama potensi timbulnya limbah dari sampah makanan (food waste). Dengan meningkatnya timbulan sampah, maka akan muncul berbagai permasalahan terutama pencemaran lingkungan dan nilai estetika yang dapat merugikan Kota Padang sebagai kota pariwisata.

Menurut Parfit dkk (2010) berdasarkan Food Agriculture Organization (FAO) sampah makanan adalah sampah yang dihasilkan pada saat proses dalam pembuatan makanan maupun setelah kegiatan makan yang berhubungan dengan perilaku penjual dan konsumennya. Masalah sampah makanan secara global menjadi perhatian khusus untuk diatasi dalam meningkatkan kelestarian lingkungan (Finn, 2011). Negara-negara di Asia, seperti Jepang telah melakukan upaya pengolahan dan pengelolaan sendiri untuk jenis sampah makanan setelah dibuatnya undang-undang baru pada tahun 2000 (Tanaka, dkk., 2008), sedangkan di Indonesia khususnya Kota Padang, pengolahan dan pengelolaan sampah makanan masih disatukan dengan sampah kota.

Undang-Undang Nomor 18 Tahun 2008 tentang Pengelolaan Sampah pasal 2, yang berisi bahwa sampah dari restoran tergolong pada sampah sejenis sampah rumah tangga. Sebagaimana dimaksud pada pasal 12 Undang-Undang tersebut bahwasannya setiap orang dalam mengelola sampah rumah tangga dan sampah sejenis sampah rumah tangga wajib mengurangi dan menangani sampah dengan cara yang berwawasan lingkungan. Menurut Peraturan Daerah Nomor 21 Tahun 2012 tentang Pengelolaan Sampah di Kota Padang masyarakat wajib ikut serta dalam pengelolaan sampah.

Pada penelitian Mezardiana (2013) di Kota Bandung yang dilakukan di 35 titik sampel didapatkan timbulan food waste sebesar $0,33 \mathrm{~kg} / \mathrm{o} / \mathrm{h}$ atau 1,09 1/o/h dengan komposisi terbesar adalah sampah organik berupa sisa-sisa makanan pengunjung, daun, sisa bahan makanan kulit buah sebesar $73 \%$, diikuti sampah plastik, tissue/ kertas dan lain-lain sebesar $12 \%, 11 \%$ dan 4\%. Analisis laboratorium untuk food waste di Bandung didapatkan kadar air sebesar $68,32 \%$ dan kadar C/N sebesar 33,69\%. Pengolahan yang tepat untuk sampah makanan di Kota Bandung adalah pengomposan.

Berdasarkan hasil penelitian Fadhil (2016) timbulan sampah rumah makan di Kota Padang sebesar $0,213 \mathrm{~kg} / \mathrm{m}^{2} / \mathrm{h}$ dengan komposisi terbesar merupakan sampah sisa makanan, plastik dan kertas. Potensi daur ulang untuk sampah kertas sebesar 74,67\%, sampah basah 44,67\%, sampah plastik 92,65\%, sampah kaca 99,35\% dan logam 98,39\%. Analisis di laboratorium didapatkan kadar air 52,74\%, kadar volatil $46,11 \%$, kadar abu $0,90 \%$ dan fixed carbon $0,25 \%$ serta rasio $\mathrm{C} / \mathrm{N}$ untuk rumah makan di Kota Padang sebesar 21,58 .

Sumatera Barat khususnya Kota Padang terkenal akan kulinernya. Jenis kuliner yang dijual di restoranrestoran di Kota Padang tidak hanya berbahan dasar daging saja, tetapi juga terdapat kuliner yang berbahan dasar ikan dan sea food. Masing masing restoran mengolah makanan dari bahan baku yang berbeda, hal ini akan menghasilkan timbulan, komposisi dan karakteristik sampah yang berbeda pada setiap jenis restoran. Oleh karena itu harus dilakukan penelitian ini untuk menghitung timbulan, komposisi, karakteristik dan potensi daur ulang food waste yang dihasilkan restoran di Kota Padang guna mengkaji pengolahan apa yang tepat untuk sampah makanan yang dihasilkan dari masing-masing restoran, sehingga masingmasing restoran bisa mengolah sampah makanan yang dihasilkannya sehingga mengurangi sampah yang masuk ke TPA.

\section{Metodologi}

\section{Studi Literatur Penentuan}

Studi literatur berfungsi untuk acuan dan dasar dalam penelitian ini yang berkaitan dengan timbulan, komposisi, dan potensi daur ulang sampah makanan restoran di Kota Padang.

\section{Pengumpulan Data}

Pengumpulan data meliputi data primer dan data sekunder. Data primer didapat dari lapangan berupa timbulan, komposisi dan potensi daur ulang sampah makanan. Data sekunder berupa klasifikasi dan jumlah restoran di Kota Padang.

\section{Sampling \\ Jumlah Sampel}

Menentukan bahwa sampel yang diambil telah mewakili dari restoran, maka dibuktikan dengan evaluasi jumlah survei menggunakan rumus 
Tabel 1. Data titik sampling sampah makanan restoran di KotaPadang

\begin{tabular}{lllcc}
\hline $\begin{array}{l}\text { Jenis } \\
\text { Restoran }\end{array}$ & $\begin{array}{l}\text { Jumlah } \\
\text { Total }\end{array}$ & Klasifikasi & Jumlah & Sampel \\
\hline \multirow{2}{*}{$\begin{array}{l}\text { Rumah } \\
\text { Makan }\end{array}$} & \multirow{2}{*}{98} & Besar & 34 & 2 \\
& & Menengah & 15 & 1 \\
Cafe & \multirow{2}{*}{67} & Kecil & 49 & 3 \\
& & Besar & 33 & 2 \\
Cepat Saji & \multirow{2}{*}{17} & Menengah & 18 & 1 \\
& & Kecil & 16 & 1 \\
Food Court & \multirow{2}{*}{48} & Besar & 7 & 1 \\
& & Kecil & 10 & 1 \\
\hline Total & 230 & Mesar & 15 & 1 \\
\hline
\end{tabular}

berdasarkan SNI 19-3964-1994 tentang Metode Pengambilan dan Pengukuran Contoh Timbulan dan Komposisi Sampah Perkotaan.

Menurut data destinasi wisata kuliner kota Padang, pada tahun 2017 tercatat sebanyak 230 usaha jasa boga seperti kafe dan restoran/ rumah makan yang terdaftar di Kota Padang. Dengan angka tersebut, maka jumlah titik sampel yang didapatkan adalah:

$$
\begin{aligned}
S & =C d \sqrt{T S} \\
S & =1 * \sqrt{230} \\
& =15
\end{aligned}
$$

\section{Penentuan Lokasi Sampling}

Berdasarkan SNI 19-3964-1994 pembagian jenis restoran dikelompokkan berdasarkan jenis kegiatannya. Sehingga pengelompokkan jenis restoran yang ada di Kota Padang bisa dilihat pada Tabel 1

\section{Penentuan Waktu Sampling}

Pengambilan sampel sampah selama 8 hari mulai tanggal 2-9 November 2018. Pengambilan sampel sampah dilakukan pada titik yang telah ditentukan. Pengambilan sampel sampah selama 24 jam dan dijemput pada malam hari pukul 21:00-22:00 WIB. Sampah kemudian diangkut ke tempat pengukuran yang direncanakan untuk dilakukan pengukuran timbulan, komposisi, karakteristik dan potensi daur ulang sampah.Pengukuran timbulan, komposisi, karakteristik fisika (berat jenis) dan potensi daur ulang sampah dilakukan di lapangan. Sedangkan untuk penelitian karakteristik sampah (karakteristik kimia dan biologi) dilakukan di Laboratorium Buangan

Tabel 2. Timbulan Sampah Makanan dalam Satuan Berat dan Volume

\begin{tabular}{lll}
\multicolumn{3}{c}{ dan Volume } \\
Restoran & Timbulan/Perhari $(\mathrm{Kg} / \mathrm{h})$ & $\begin{array}{l}\text { Timbulan } \\
(\mathrm{l} / \mathrm{h})\end{array}$ \\
\hline Rumah Makan & 24 & 212 \\
\hline Café & 10 & 92 \\
\hline Fast Food & 11 & 100 \\
\hline Food Court & 13 & 120 \\
\hline Rata-rata & 15 & 132 \\
\hline
\end{tabular}

Tabel 3. Satuan timbulan sampah makanan restoran di Kota Padang

\begin{tabular}{lllll}
\hline \multirow{2}{*}{ Restoran } & \multicolumn{2}{l}{ Satuan Berat } & \multicolumn{2}{l}{ Satuan Volume } \\
\cline { 2 - 5 } & $(\mathrm{kg} / \mathrm{o} / \mathrm{h})$ & $\left(\mathrm{kg} / \mathrm{m}^{2} / \mathrm{h}\right)$ & $(\mathrm{l} / \mathrm{o} / \mathrm{h})$ & $\left(1 / \mathrm{m}^{2} / \mathrm{h}\right)$ \\
\hline Rumah Makan & 0,088 & 0,222 & 0,464 & 1,162 \\
\hline Café & 0,119 & 0,146 & 1,182 & 1,447 \\
\hline Fast Food & 0,081 & 0,102 & 1,318 & 1,642 \\
\hline Food Court & 0,133 & 0,085 & 0,856 & 0,549 \\
\hline Rata-rata & 0,105 & 0,139 & 0,955 & 1,200 \\
\hline
\end{tabular}

Padat Jurusan Teknik Lingkungan Fakultas Teknik Universitas Andalas.

\section{Tempat Penelitian}

Penelitian ini dilakukan dibeberapa tempat yaitu, perhitungan timbulan, komposisi, karakteristik fisik dan potensi daur ulang sampah makanan di lapangan serta analisis karakteristik kimia dan biologi sampah dilakukan di Laboratorium Buangan Padat (LBP) Jurusan Teknik Lingkungan, Universitas Andalas.

\section{Hasil dan Pembahasan}

\subsection{Satuan Timbulan dan Timbulan Sampah Makanan Restoran di Kota Padang}

Timbulan sampah makanan restoran di Kota Padang per hari dalam satuan berat dan volume bisa dilihat pada Tabel 2 .

Timbulan sampah makanan restoran di Kota Padang dalam satuan berat dan volume terbesar yaitu pada rumah makan, hal ini dikarenakan rumah makan memiliki rata-rata pengunjung paling banyak per harinya. Timbulan sampah makanan rumah makan juga terdapat banyak sampah organik berupa sisa makanan pengunjung yang mempengaruhi berat sampah yang dihasilkan. Sampah rumah makan juga didominasi sampah plastik berupa botol dan kemasan plastik yang digunakan dalam pengolahan makanan di rumah makan maupun saat penyajiannya.

Sampah makanan yang berasal dari cafe memiliki nilai paling kecil, hal ini disebabkan berat sampah pada cafe kecil setiap komposisi yang dihasilkan. Sampah makanan pada cafe memiliki komposisi yang sama dengan sampah makanan rumah makan, fast food maupun food court namun pada cafe sampah tersebut tidak sebanyak yang dihasilkan rumah makan.

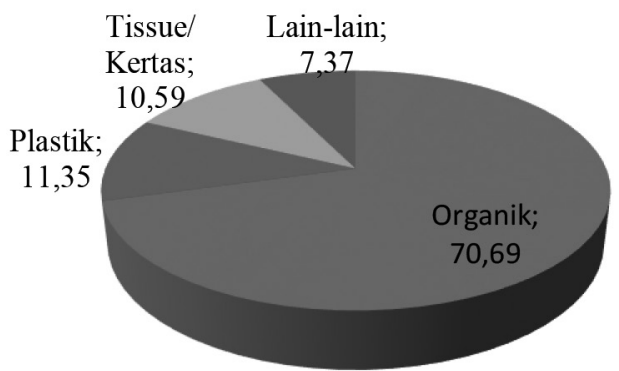

Gambar 1. Komposisi sampah makanan restoran di Kota Padang 


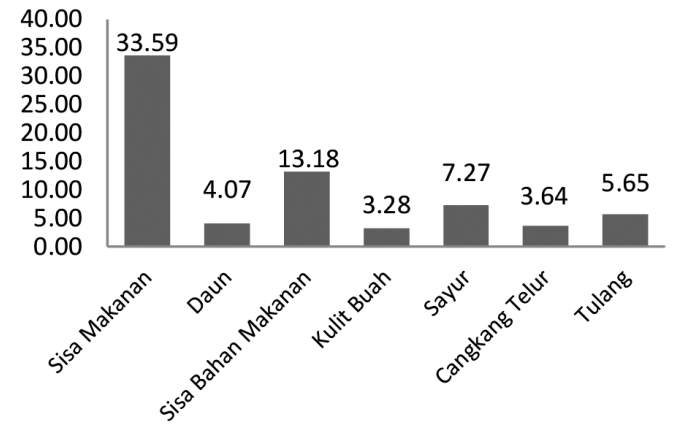

Gambar 2. Komposisi sampah organik

Dari Tabel 3 dapat dilihat bahwa satuan timbulan rata-rata sampah makanan restoran di Kota Padang dalam satuan berat sebesar $0,105 \mathrm{~kg} / \mathrm{o} / \mathrm{h}$ dan 0,139 $\mathrm{kg} / \mathrm{m}^{2} / \mathrm{h}$ dan dalam satuan volume sebesar $0,955 \mathrm{l} / \mathrm{o} / \mathrm{h}$ dan $1,2001 / \mathrm{m}^{2} / \mathrm{h}$. Satuan timbulan terbesar dalam satuan $\mathrm{kg} / \mathrm{o} / \mathrm{h}$ berasal dari food court. Satuan timbulan terbesar dalam $\mathrm{kg} / \mathrm{m}^{2} / \mathrm{h}$ berasal dari rumah makan. Sedangkan satuan timbulan terbesar dalam satuan 1/o/h maupun $1 / \mathrm{m}^{2} / \mathrm{h}$ berasal dari fast food. Satuan timbulan fast food ini dipengaruhi oleh jumlah sampah kertas/ tissue maupun sampah plastik yang dihasilkan, hal ini mengakibatkan besarnya volume sampah yang dihasilkan.

\subsection{Komposisi Sampah Makanan Restoran di Kota Padang}

Komposisi sampah makanan restoran di Kota Padang dapat dilihat pada Gambar 1.

Hasil penelitian untuk komposisi sampah makanan restoran di Kota Padang menunjukkan bahwa komposisi terbanyak adalah sampah organik dengan persentase $70,69 \%$, sedangkan persentase sampah plastik sebesar $11,35 \%$. Komposisi sampah organik yang mendominasi sampah makanan restoran di Kota Padang adalah sampah sisa makanan pengunjung, sampah sisa bahan makanan dan sampah sayur.

Untuk sampah organik komponen terbesar merupakan sampah sisa makanan yang berasal dari pengunjung sebesar $33,59 \%$. Selanjutnya sampah sisa

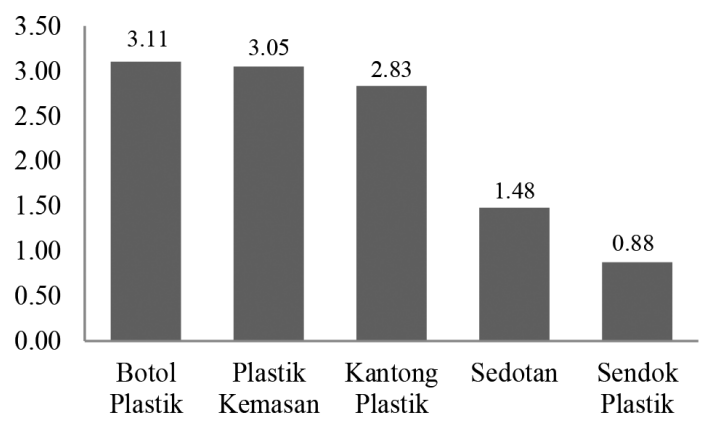

Gambar 3. Persentase sampah plastik

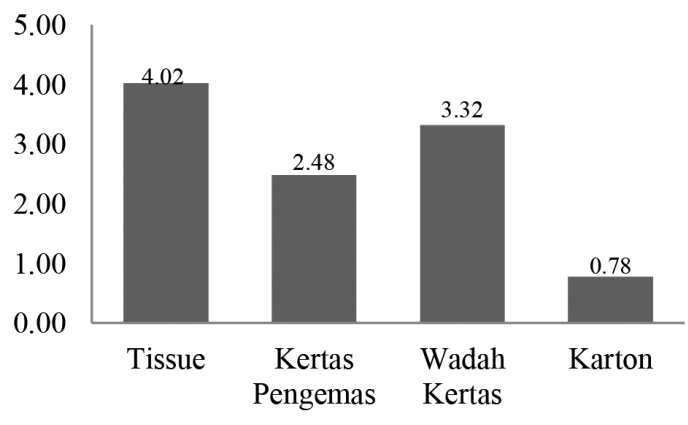

Gambar 4. Persentase sampah kertas

bahan makanan $13,18 \%$, sayur $7,27 \%$, tulang $5,65 \%$, cangkang telur 3,64 dan kulit buah 3,28\%. Persentase sampah organik bisa dilihat pada Gambar 2

Untuk sampah plastik komponen terbesar merupakan sampah botol plastik sebesar 3,11\%. Selanjutnya plastik kemasan 3,05\%, kantong plastik $2,83 \%$, sedotan $1,48 \%$ dan sendok plastik $0,88 \%$. Persentase sampah plastik bisa dilihat pada Gambar 3

Untuk sampah tissue/ kertas komponen terbesar merupakan sampah tissue yang sebesar 4,02\%. Selanjutnya sampah wadah kertas 3,32\%, kertas pengemas $2,48 \%$, dan karton $0,78 \%$. Persentase sampah tissue/ kertas bisa dilihat pada Gambar 4.

Untuk sampah lain-lain komponen terbesar merupakan sampah botol sebesar 2,34\%. Selanjutnya sampah kaleng $2,18 \%$, pecahan kaca $1,57 \%$, sisa rokok $0,85 \%$ dan styrofoam $0,43 \%$. Persentase sampah lainlain bisa dilihat pada Gambar 5 .

\section{Komposisi Sampah Makanan Rumah Makan}

Komposisi sampah makanan rumah makan didominasi oleh sampah organik $76,66 \%$ berupa sisa makanan sebesar 38,23\%, sisa bahan makanan sebesar $14,60 \%$ dan sampah sayur sebesar $8,24 \%$. Besarnya komposisi sampah organik pada rumah makan disebabkan karena titik sampling yang diambil saat penelitian banyak menghasilkan sampah sisa makanan pengunjung dan sampah sisa-sisa saat melakukan pengolahan makanan sebelum penyajiannya.

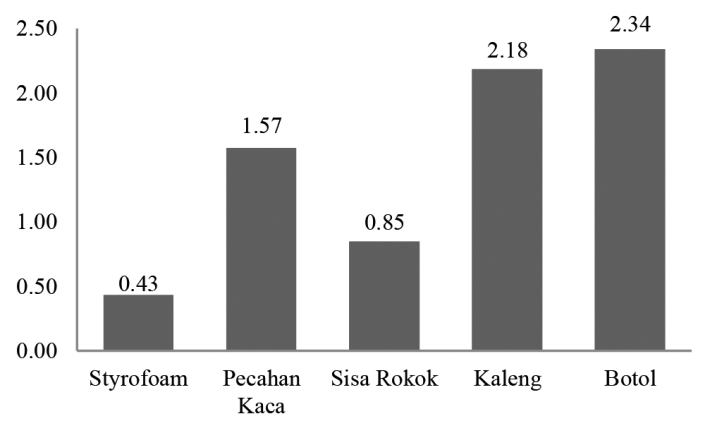

Gambar 5. Persentase sampah lain-lain 
Tabel 4. Rekapitulasi potensi daur ulang sampah makanan restoran di Kota Padang

\begin{tabular}{llll}
\hline Jenis Sampah & $\begin{array}{l}\text { Layak } \\
\text { kompos }\end{array}$ & $\begin{array}{l}\text { Dapat didaur } \\
\text { ulang }\end{array}$ & $\begin{array}{l}\text { Tidak dapat } \\
\text { didaur ulang }\end{array}$ \\
\hline Kertas (\%) & - & 7,65 & 92,35 \\
\hline Plastik (\%) & - & 51,32 & 48,68 \\
\hline Kaca (\%) & - & 59,86 & 40,14 \\
\hline Besi (\%) & - & 100,00 & - \\
\hline Organik (\%) & 91,71 & - & 8,29 \\
\hline
\end{tabular}

\section{Komposisi Sampah Makanan Fast Food}

Komposisi sampah makanan restoran cepat saji didominasi oleh sampah organik $60,13 \%$ berupa sisa makanan sebesar $26,41 \%$ dan sisa bahan makanan sebesar $11,20 \%$. Selain itu komposisi sampah restoran cepat saji juga didominasi oleh sampah tissue. Besarnya sampah sisa makanan yang di dapatkan pada sampel restoran cepat saji ini disebabkan karena pada umumnya sampah yang dihasilkan di tempat ini adalah sampah berupa sisa-sisa nasi dan tulang-tulang. Sampah tissue dipengaruhi banyaknya penggunaan tissue oleh pengunjung setelah makan.

\section{Komposisi Sampah Makanan Food Court}

Komposisi sampah makanan food court didominasi oleh sampah organik $71,42 \%$ berupa sisa makanan sebesar $34,17 \%$ dan sisa bahan makanan sebesar $13,09 \%$. Besarnya sampah sisa makanan yang di dapatkan pada sampel food court ini disebabkan karena pada umumnya sampah yang dihasilkan di tempat ini adalah sampah berupa sisa-sisa nasi dan makanan yang tidak habis dimakan oleh pengunjung dan bahan-bahan saat melakukan pengolahan makanan.

\section{Komposisi Sampah Makanan Cafe}

Komposisi sampah makanan cafe didominasi oleh sampah organik $70,69 \%$ berupa sampah sisa makanan sebesar 35,57\% dan sisa bahan makanan sebesar $13,83 \%$. Besarnya sampah sisa makanan yang di dapatkan pada sampel cafe ini disebabkan karena pada umumnya sampah yang dihasilkan di tempat ini adalah sampah berupa sisa-sisa makanan dari pengunjung.

\subsection{Potensi Daur Ulang Sampah Makanan Restoran di Kota Padang}

Persentase komposisi sampah makanan yang didapatkan berdasarkan komponen sampah dari penelitian berguna untuk penentuan potensi daur ulang dari masing-masing komponen. Penentuan potensi daur ulang dari masing-masing komponen sampah didapatkan dengan membandingkan berat masing-masing komponen yang dapat didaur ulang dengan berat total masing-masing komponen sampah. Potensi daur ulang berdasarkan sumber sampah dikelompokkan atas potensi daur ulang sampah basah dan potensi daur ulang sampah kering. Komponen tersebut berupa sampah logam, kaca, kertas, organik dan plastik.

Potensi daur ulang sampah makanan restoran di Kota Padang untuk sampah organik sebesar 91,71\%, sampah kertas sebesar 7,65\%, sampah plastik 51,32\%, sampah kaca 59,86\% dan sampah logam 100\%. Sampah kertas memiliki potensi daur ulang yang paling kecil karena sampah kertas yang dihasilkan banyak dijumpai sampah tisu bekas dan pengemas makanan yang tidak bisa didaur ulang.

Berdasarkan Tabel 4 potensi daur ulang terbesar terdapat pada sampah jenis besi karena dari penelitian yang dilakukan jumlah sampah besi yang ditemukan hanya logam non ferrous yang bisa di daur ulang, sampah ini berasal dari minuman kaleng, kaleng kemasan dan lain-lain. Potensi daur ulang sampah kedua terbesar adalah sampah kaca berupa botol minuman dari sampah pengunjung maupun pedagang. Sedangkan sampah layak kompos didapatkan sebesar $18,34 \%$ berasal dari sampah organik. Untuk sampah plastik hanya sedikit yang dapat didaur ulang, hal ini karena sampah ini berasal dari kemasan plastik, kantong plastik yang, dan sedotan yang tidak bisa didaur ulang.

\subsection{Rekomendasi Upaya Daur Ulang Sampah Makanan Restoran di Kota Padang}

Komponen sampah yang mempunyai nilai tinggi untuk dimanfaatkan kembali, berdasarkan kondisi eksisting dan penelitian Hafizh (2016) di Kota Padang adalah sampah kertas, plastik, logam dan kaca. Sehingga diperkirakan komponen sampah yang dapat didaur ulang untuk masa yang akan datang, berkisar kepada empat jenis sampah tersebut yaitu sampah kertas, plastik, logam dan kaca. Hasil penelitian didapatkan untuk potensi daur ulang sampah makanan cukup tinggi terutama untuk sampah logam non ferrous dimana potensi daur ulangnya mencapai $100 \%$ yang terdiri dari sampah kaleng minuman dan kaleng-kaleng yang digunakan dalam pengolahan maupun penyajian dalam aktivitas restoran di Kota Padang. Sampah kaca memiliki potensi daur ulang sampah sebesar 51,32\%, sampah ini terdiri dari botol minuman yang dapat didaur ulang.

Untuk sampah organik potensi daur ulang untuk pengomposan sebesar $91,71 \%$. Potensi ini tergolong tinggi karena hampir mencapai $100 \%$. Sampah ini terdiri dari sampah sisa makanan restoram sayuran, kulit buah dan lain-lain yang bisa digunakan sebagai bahan dasar pengomposan. Menurut penelitian Farrel 
(2009) menunjukkan bahwa kompos hasil dari sampah makanan memiliki karakteristik kompos yang bagus, dengan memiliki rasio $\mathrm{C} / \mathrm{N}$ yang cukup menggantikan tanah gambut untuk tanaman holtikultura. Pada penelitian Joung Dae-Kim (2007) juga menyebutkan bahwa sampah makanan cocok digunakan untuk bahan dasar pengomposan, dimana pada penelitian tersebut digunakan metode in-vessel composting.

Proses pengomposan adalah proses dekomposisi materi organik menjadi pupuk kompos melalui reaksi biologis mikroorganisme secara aerobik dalam kondisi terkendali. Pengomposan sendiri merupakan proses penguraian senyawa-senyawa yang terkandung dalam sisa-sisa bahan organik (seperti jerami, daun-daunan, sampah rumah tangga, sisa makanan, kulit buah dan sebagainya) dengan suatu perlakuan khusus (Nugroho, 2006).

Jika masing-masing restoran di Kota Padang menerapkan daur ulang ini maka akan mengurangi sampah yang masuk ke TPA. Sampai saat ini TPA di Kota Padang masih menerapkan sistem open dumping, dimana sampah ditumpuk di atas tanah dan tidak memperhatikan aspek sanitasi (Loeis, 2005). Jika sampah restoran ini terus menerus dibuang ke TPA tentu akan menimbulkan pencemaran, baik pencemaran tanah maupun air tanah. Untuk itu mendaur ulang sampah makanan restoran tersebut merupakan salah satu upaya untuk menanggulangi dampak negatif yang ditimbulkan dan untuk mengurangi jumlah sampah yang masuk ke TPA.

\section{Kesimpulan}

Kesimpulan hasil penelitian kajian pengolahan sampah makanan restoran di Kota Padang adalah sebagai berikut:

1. Satuan timbulan sampah makanan restoran di Kota Padang tahun 2018 dalam satuan berat adalah $0,105 \mathrm{~kg} / \mathrm{o} / \mathrm{h}$ atau $0,139 \mathrm{~kg} / \mathrm{m}^{2} / \mathrm{h}$ dan dalam satuan volume adalah0,955 1/o/h atau 1,200 1/m²/h;

2. Komposisi sampah makanan restoran di Kota Padang tahun 2018 yang berturut-turut dari yang terbanyak adalah sampah organik 70,69\% dengan komponen terbesar adalah sampah sisa makanan,sampah plastikyaitu 11,35\% dengan komponen terbesar adalah sampah botol plastik, sampah kertas/ tissue10,59\% dengan komponen terbesar adalah tissue, sampah lainlain 7,37\% dengan komponen terbesar adalah botol;

3. Potensi daur ulang sampah makanan berturutturut dari yang terbesar yaitu sampah logam non ferrous $100 \%$, sampah plastik 51,32\%, sampah kaca 59,86\%, sampah organik 91,71\% dan sampah kertas $7,65 \%$.

Adapun saran yang diberikan terhadap hasil penelitian ini adalah:

1. Penelitian bisa dilanjutkan dengan kajian pengolahan sampah makanan restoran di Kota Padang;

2. Sebaiknya pihak restoran mengurangi penggunaan sendok plastik, sedotan maupun kemasan makanan yang tidak bisa didaur ulang.

\section{Daftar Pustaka}

Badan Standardisasi Nasional.(1994). Metode Pengambilan dan Pengukuran Contoh Timbulan dan Komposisi Sampah Perkotaan, Indonesia. Nomor Publikasi: SNI-19-3964-1994

Damanhuri, E. dan Padmi, T. (2016). Pengelolaan Sampah Terpadu. Bandung: Teknik Lingkungan Institut Teknologi Bandung (ITB)

Dinas Pariwisata Kota Padang. (2017). Jumlah Restoran di Kota Padang

Fadhil, M. (2012). Studi Timbulan, Komposisi, Karakteristik dan Potensi Daur Ulang Sampah Komersil Kota Padang. Padang: Jurusan Teknik Lingkungan

Farrell, M. (2009). Food waste composting: Its use as a peat replacement. Waste Management. 30 (8-9)

Finn, S M. (2011). A Public-Private Initiative to Reduce Food Waste: A Framework for Local Communities. Graduate Studies Journal of Organizational Dynamics. Vol. 1 (1)

Hafizh, M. (2016). Timbulan, Komposisi, Karakteristik dan Potensi Daur Ulang Sampah Domestik Kota Padang: Universitas Andalas: Teknik Lingkungan

Kim, J D. (2007). Evaluation of pilot-scale in-vessel composting for food waste treatment. Journal of Hazardous Materials. Volume 154. Issues 103. Page 272-277

Loeis, N. (2005). Pengaruh Sistem Open Dumping terhadap Karakteristik Lindi di Tempat Pembuangan Akhir (TPA) Sampah Air Dingin Padang. Padang: Teknik Lingkungan

Mezardiana, A M dan Rahardyan, B. (2013). Studi Awal Timbulan, Komposisi dan Karakteristik Food Waste. Bandung: ITB

Nugroho, D A. (2006). Pembuatan Kompos dengan Menggunakan Limbah Padat Organik. Semarang: Universitas Diponegoro

Parfitt, J, Berthel, M, dan Macnaughton, S. (2010). Foodwaste Within Food Supply Chain: Quantification and potential for Change to 2050, Phil. Trans. R. Soc., vol. 365,pp 3065-3081

Peraturan Daerah Kota Padang. (2012). Pengelolaan Sampah. Kota Padang

Tanaka, M. (2008). Basic Characteristic of Food Waste and Food Ash on Steam Gasification. Industrial \& Engineering Chemistry Research. Vol. 47. Issues 7. Page 2.414-2.419

Undang-Undang Republik Indonesia Nomor 18 Tahun 2008 Tentang Pengelolaan Sampah 